\title{
URBAN DEVELOPMENT AND ECONOMIC-FINANCIAL INDICATORS CORRELATION IN TIRANA, ALBANIA
}

\author{
Otjela LUBONJA ${ }^{1 *}$, Admir JANÇE ${ }^{2}$ \\ $I^{1 *}$ European University of Tirana, Department of Engineering and Architecture, Tirana, Albania; \\ ${ }^{2}$ European University of Tirana, Imaging Department, Tirana, Albania; \\ *Corresponding Author Otjela Lubonja, e-mail: otjela.lubonja@uet.edu.al; \\ admir.jance@uet.edu.al;
}

Received December 2021; Accepted January 2022; Published February 2022;

DOI: https://doi.org/10.31407/ijees12.209

\begin{abstract}
Through this paper we have tried to provide an in-depth analysis in the field of urbanization by answering some questions which are important to understand the impact of urbanization and the economy on each other, for the Capital of Albania, Tirana. Tirana town in the last 30 years has undergone a real revolution accompanied by a series of complex changes both in economic and social terms. The study aims to present the contribution of urbanization to the development of a country and to make the connection between urbanization and the economy. Through the analysis of the obtained results we have tried to interpret the impact of Foreign Investments in the urbanization of Tirana City, to determine where is the highest life expectancy of residents and where are the most developed enterprises - in urban or rural areas. The results we draw from this study guarantee the right success in the urban plan. The novelty of this study is the correlation between two important components such as urbanization and the economy, which help the economic growth of a country. This study promotes comprehensive collaboration between academia and government institutions, and local communities to articulate proposals on which sectors should intervene to encourage economic growth. Only in this way can we offer some concrete improvements such as social, cultural, environmental and economic, etc. From this study we will understand that the expansion of urbanization leads to an increase in Gross Domestic Product and vice versa. From the results obtained during this paper it is clear that Foreign Direct Investment has a positive impact on economic growth and urbanization in Albania, while energy consumption has no positive impact on urbanization.
\end{abstract}

Keywords: Urban development, Economic growth, Foreign Investment, Gross Domestic Product, Tirana city, Albania. 